\title{
Financial Integration and Macroeconomic Volatility
}

\section{AYHAN KOSE, ESWAR S. PRASAD, and MARCO E. TERRONES*}

This paper examines the impact of international financial integration on macroeconomic volatility. Economic theory does not provide a clear guide to the effects of financial integration on volatility, implying that this is essentially an empirical question. We provide a comprehensive examination of changes in macroeconomic volatility in a large group of industrial and developing economies over the period 1960-99. We report two major results: First, while the volatility of output growth has, on average, declined in the 1990s relative to the three earlier decades, we also document that, on average, the volatility of consumption growth relative to that of income growth has increased for more financially integrated developing economies in the 1990s. Second, increasing financial openness is associated with rising relative volatility of consumption, but only up to a certain threshold. The benefits of financial integration in terms of improved risk-sharing and consumption-smoothing possibilities appear to accrue only beyond this threshold.

nternational financial integration is believed to have two major potential benefits-improving the global allocation of capital and helping countries to better share risk by reducing consumption volatility. Given their relatively low levels of physical capital and their inherently greater volatility, developing economies, in particular, seem to have the most to gain from this process of integration. As policymakers in developing economies evaluate the benefits and risks

\footnotetext{
${ }^{*}$ M. Ayhan Kose is an Economist in the Western Hemisphere Department of the International Monetary Fund. Eswar Prasad is Chief of the China Division in the Asia and Pacific Department of the International Monetary Fund. Marco E. Terrones is a Senior Economist in the Research Department of the International Monetary Fund. The authors are grateful to Hideaki Hirata, Henry Kim, Roberto Rigobon, Michel Robe, Shang-Jin Wei, an anonymous referee, numerous colleagues, and seminar participants at the IMF and the World Bank for helpful comments and discussions and to Gian Maria MilesiFerretti for generously sharing his data.
} 


\section{Ayhan Kose, Eswar S. Prasad, and Marco E. Terrones}

of financial integration, understanding its implications for growth as well as volatility has taken on great importance.

There has been a rigorous debate about the impact of financial integration on growth. The evidence on the long-term benefits of financial globalization suggests that, notwithstanding the crises that have wracked some of them, more financially integrated economies have done better, on average, than less-integrated economies in terms of improvements in per capita income and standards of living. Moreover, several recent papers have examined various dimensions of the causal link from financial integration to growth. ${ }^{1}$ Although many of these studies conclude that financial integration does generate growth benefits, this relationship is not always found to be strong or robust.

There has also been an intensive discussion about the impact of financial integration on macroeconomic volatility. However, this discussion seems to be relatively uninformed since the available empirical evidence on the effects of financial integration on volatility is far more limited. The objective of this paper is to shed some light on this issue by studying the impact of international financial integration on macroeconomic volatility. In this context, we address three questions: First, what are the implications of economic theory for the effect of financial integration on volatility? Second, what are the dynamics of macroeconomic volatility over time and across different groups of countries? Third, is there an empirical link between the degree of international financial integration and volatility?

Understanding the dynamics of macroeconomic volatility has recently come to the fore for a number of reasons. First, a burgeoning literature that has documented a negative relationship between volatility and growth (see Ramey and Ramey, 1995) implies that volatility has first-order effects on welfare, even for developing economies where growth has traditionally been the major concern. ${ }^{2}$ Second, more recently, a number of papers have documented the declining volatility of output in the United States and most industrial economies since the mid-1980s and examined the sources of this change (see Blanchard and Simon, 2001, and McConnell and Perez-Quiros, 2000). It is of obvious interest to examine if the phenomenon of declining volatility in the mid-1990s is limited to industrial economies. Third, the welfare implications of volatility in developing economies have been highlighted by episodes of extreme volatility - that is; crises-in a number of developing economies in the 1980s and 1990s. While developing economies have continued to become more open to trade, the more dramatic change over this period has been the surge in the volume of financial flows from the industrialized countries to developing countries. Hence, a natural question is whether rising financial integration of developing economies by itself has an impact on volatility.

In the next section, we review the results of some recent theoretical and empirical studies focusing on the relationship between economic integration and volatility. The message of this section is twofold. First, economic theory does not provide

\footnotetext{
${ }^{1}$ Prasad, Rogoff, Wei, and Kose (2003) examine various dimensions of international financial integration. See Edison, Klein, Ricci, and Slok (2002) for a survey about the effects of financial integration on growth.

${ }^{2}$ Prasad, Rogoff, Wei, and Kose (2003) provide a review of this literature and report that developing countries can get large welfare gains from international risk-sharing. Pallage and Robe (2003) report that welfare gains associated with consumption smoothing are quite large in several African countries.
} 
a clear guide to the effects of either trade or financial integration on macroeconomic volatility. Hence, this is essentially an empirical question. On the other hand, a number of standard models do suggest that, under general conditions, financial integration should be expected to lead to a decline in the relative volatility of consumption.

In order to examine the effects of financial integration, we begin with a broadbrush classification of developing economies into two groups: more financially integrated economies (MFIEs) and less financially integrated economies (LFIEs). ${ }^{3}$ We first study the volatility of output and consumption in these two groups and in industrialized countries. In order to explore how different sources of volatility affect the ability to smooth consumption in response to a given realization of shocks, we also analyze the volatility of consumption relative to that of output.

We then present an overview of changes in macroeconomic volatility over time. While the volatility of output growth has, on average, declined in the 1990s relative to the three earlier decades, we find that, on average, the volatility of consumption growth relative to that of income growth has increased for MFIEs in the 1990s. This is precisely the period when financial integration, as measured by financial flows to and from these economies, increased substantially. Notice that our use of a measure of the volatility of consumption relative to that of income implies that this result can not be explained away as just a consequence of some of these economies having undergone crises during this period.

After documenting these basic results, in Section IV we conduct a systematic empirical analysis to examine what factors, either macroeconomic or structural, are associated with both the level of relative consumption volatility and its evolution over time. One of the main results of this analysis is that financial openness, as measured by gross capital flows as a ratio to GDP, is associated with an increase in the ratio of consumption volatility to income volatility, contrary to the notions of improved international risk-sharing opportunities through financial integration. However, this relationship is nonlinear. Once the level of gross capital flows crosses a particular threshold, it appears to have a negative effect on this ratio. Indeed, industrial economies, which typically have much larger gross capital flows (as a share of GDP), appear to have benefited the most from this form of financial integration, at least in terms of the relative volatility of consumption.

\section{An Overview of Theoretical and Empirical Studies}

Understanding the impact of financial and/or trade integration on macroeconomic volatility has remained a major challenge for both theoretical and empirical studies. This section provides an overview of the theory and available empirical evidence about the effects of trade and financial integration on volatility. While our main focus is on the impact of financial integration, we also study the implications of trade integration for macroeconomic volatility considering that recent research makes a convincing case about the complementary nature of trade integration and financial integration (see IMF, 2002).

${ }^{3}$ The criteria used to make this distinction are discussed in Prasad, Wei, and Kose (2003). The MFIEs largely comprise what are traditionally referred to as "emerging markets." The Data Appendix provides a listing of both groups of countries in our sample. 


\section{Ayhan Kose, Eswar S. Prasad, and Marco E. Terrones}

\section{Theory}

A cursory review of the literature suggests that the theoretical impact of financial integration on business cycle volatility is ambiguous. Mendoza (1994) employs a stochastic dynamic business cycle model and finds that quantitative changes in the volatility of output and consumption are quite small in response to the changes in the degree of financial integration. He also finds that when shocks are larger and more persistent, the volatility of output increases with the degree of financial integration. Baxter and Crucini (1995) find that the volatility of output increases while the volatility of consumption (and the relative volatility of consumption) decreases with rising financial integration. The difference between the changes in the volatility of output and consumption is mostly due to the wealth effects and the interaction of these effects with the risk-sharing implications of different asset market structures.

The theoretical impact of trade integration on macroeconomic volatility depends greatly on patterns of trade specialization and the nature of shocks. ${ }^{4}$ If trade openness is associated with increased interindustry specialization across countries and industry-specific shocks are important in driving business cycles, the result could be a rise in output volatility (see Krugman, 1993). If these shocks are highly persistent, then they could increase the volatility of consumption as well. However, if increased trade is associated with increased intraindustry specialization across countries, which leads to a larger volume of intermediate inputs trade, then the volatility of output could decline (see Razin and Rose,1994). These results indicate that the impact of trade integration on volatility is also ambiguous in theory.

Some recent studies consider the impact of financial openness on macroeconomic volatility using dynamic stochastic sticky-price models, which are based on the Redux model of Obstfeld and Rogoff (1995). ${ }^{5}$ Sutherland (1996), Senay (1998), and Buch, Dopke, and Pierdzioch (2002) consider the importance of monetary and fiscal policy shocks in the context of such models. The results of these studies suggest that the impact of financial integration on the volatility of output and consumption depend on the nature of shocks. In the presence of monetary (fiscal) policy shocks, the volatility, of output increases (decreases) while the volatility of consumption decreases (increases) as the degree of financial integration increases.

The relationship between financial openness and macroeconomic volatility could also be affected by the structural characteristics of developing countries, which make them more vulnerable to shocks originating in other countries. First, limited diversification of exports and imports make some of these countries particularly susceptible to sudden fluctuations in terms of trade and foreign demand shocks. Using dynamic small open economy models, Kose (2002) finds that terms of trade shocks can explain a sizable fraction of volatility, and Senhadji (1998) shows the important role played by the foreign demand shocks.

\footnotetext{
${ }^{4}$ Kose and Yi (2003) discuss the implications of trade integration on the dynamics of business cycles.

${ }^{5}$ Lane (2001) and Sarno (2001) provide surveys of the rapidly growing research program that employs sticky-price models.
} 
Second, sudden changes in the direction of capital flows are able to induce boom-bust cycles in developing countries, most of which do not have deep financial sectors to cope with the highly volatile capital flows. Aghion, Banerjee, and Piketty (1999) and Caballero and Krishnamurthy (2001) construct models that establish theoretical links between low financial sector development and high output volatility. Moreover, sudden changes in world interest rates might cause substantially large business cycle fluctuations in highly indebted countries. ${ }^{6}$

Third, country size is an important factor and developing economies are relatively much smaller than industrialized countries. Head (1995) and Crucini (1997) show that productivity fluctuations in large industrialized countries can have a significant impact on the dynamics of business cycles in small open developing countries. Kose and Prasad (2002) find that both terms of trade shocks and foreign aid flows are particularly important in accounting for highly volatile macroeconomic fluctuations in small states (defined as countries with a population below 1.5 million), which seem to exhibit higher degrees of trade and financial openness than do other developing countries.

While the sources of recent financial crises in emerging market economies are numerous, a number of such crises have occurred following financial liberalization programs (see Kaminsky and Reinhart, 1999, and Glick and Hutchison, 1999). These crises have often coincided with a sudden loss of access to world financial markets ("sudden stops" à la Calvo, 1998) and resulted in highly volatile fluctuations in output and consumption. Mendoza (2002) and Arellano and Mendoza (2002) find that the possibility of sudden stops due to borrowing constraints does not induce any sizable changes in the volatility of output and consumption.

\section{Review of the Empirical Evidence}

Unlike the rich empirical literature focusing on the impact of financial openness on economic growth, there are only a limited number of studies analyzing the links between openness and macroeconomic volatility. Moreover, existing studies have generally been unable to document a clear empirical link between openness and macroeconomic volatility. Razin and Rose (1994) study the impact of trade and financial openness on the volatility of output, consumption, and investment for a sample of 138 countries over the period 1950-88. They find no significant empirical link between openness and macroeconomic volatility. ${ }^{7}$ Easterly, Islam, and Stiglitz (2001) explore the sources of macroeconomic volatility using data for a sample of 74 countries over the period 1960-97. They find that a higher level of development of the domestic financial sector is associated with lower volatility. On the other hand, an increase in the degree of trade openness leads to an increase in the volatility of output, especially in developing countries. Their results indicate that neither financial openness nor the volatility of capital flows has a significant impact on macroeconomic volatility. They argue that, since the financial sector

\footnotetext{
${ }^{6}$ Blankenau, Kose, and Yi (2001) show that world interest rate shocks are able to explain a significant fraction of business cycle volatility in small open economies.

${ }^{7}$ The results by Karras and Song (1996) suggest that trade openness is positively associated with output volatility in 24 OECD countries.
} 


\section{Ayhan Kose, Eswar S. Prasad, and Marco E. Terrones}

transmits the impact of capital flow volatility to the real economy, the effect of capital flows is reflected in financial sector variables. ${ }^{8}$

Buch, Dopke, and Pierdzioch (2002) use data for 25 OECD countries to examine the link between financial openness and business cycle volatility. They report that there is no consistent empirical relationship between financial openness and the volatility of output. Gavin and Hausmann (1996) study the sources of macroeconomic volatility in developing countries over the period 1970-92. They find that there is a significant positive association between the volatility of capital flows and output volatility. O'Donnell (2001) examines the effect of financial integration on the volatility of output growth over the period 1971-94 using data for 93 countries. $\mathrm{He}$ finds that a higher degree of financial integration is associated with lower (higher) output volatility in OECD (non-OECD) countries. His results also suggest that countries with more developed financial sectors are able to reduce output volatility through financial integration. Bekaert, Harvey, and Lundblad (2002) examine the impact of equity market liberalization on the volatility of output and consumption during 1980-2000. They find that, following equity market liberalizations, there is a significant decline in both output and consumption volatility. Capital account openness reduces the volatility of output and consumption, but its impact is smaller than that of equity market liberalization. However, they also report that capital account openness increases the volatility of output and consumption in emerging market countries. IMF (2002) provides evidence indicating that financial openness is associated with lower output volatility in developing countries.

\section{Macroeconomic Volatility: Data Issues and Basic Stylized Facts}

We first present some stylized facts concerning output and consumption volatility. ${ }^{9}$ Figure 1 plots the volatilities of per capita output and consumption growth against purchasing power parity-adjusted real per capita income levels (expressed relative to the United States), a measure of a country's level of economic development. As anticipated, high-income countries tend to have lower output volatility than lowincome countries. This negative relationship is even more pronounced in the case of consumption. Table 1 (column 1) shows the cross-sectional medians of the volatility of output and consumption growth over the full sample, 1960-99. As noted earlier, we split developing countries into two groups: MFIEs and LFIEs. The results line up as expected, with median volatility of output and consumption being lowest for the industrial country subsample and, among developing countries, for the MFIEs, which tend to be richer and more industrialized than the LFIEs.

Next, we refine the measure of income in two ways. First, we use GNP instead of GDP. Cyclical variations in net factor income flows, as reflected in GNP, would be expected to capture the effects of international risk sharing on national income. Second, we adjust output for terms of trade effects. Terms of trade shocks are

\footnotetext{
${ }^{8}$ Denizer, Iyigun, and Owen (2002) also study the impact of financial sector development on the volatility of output, consumption, and investment and find that there is a robust negative relationship between the level of financial sector development and macroeconomic volatility.

${ }^{9}$ Output is defined as per capita real GDP while consumption is per capita real private consumption. See the Data Appendix for a more detailed description of the dataset.
} 
FINANC IAL INTEG RATION AND MACROECONOMIC VOLATILTTY

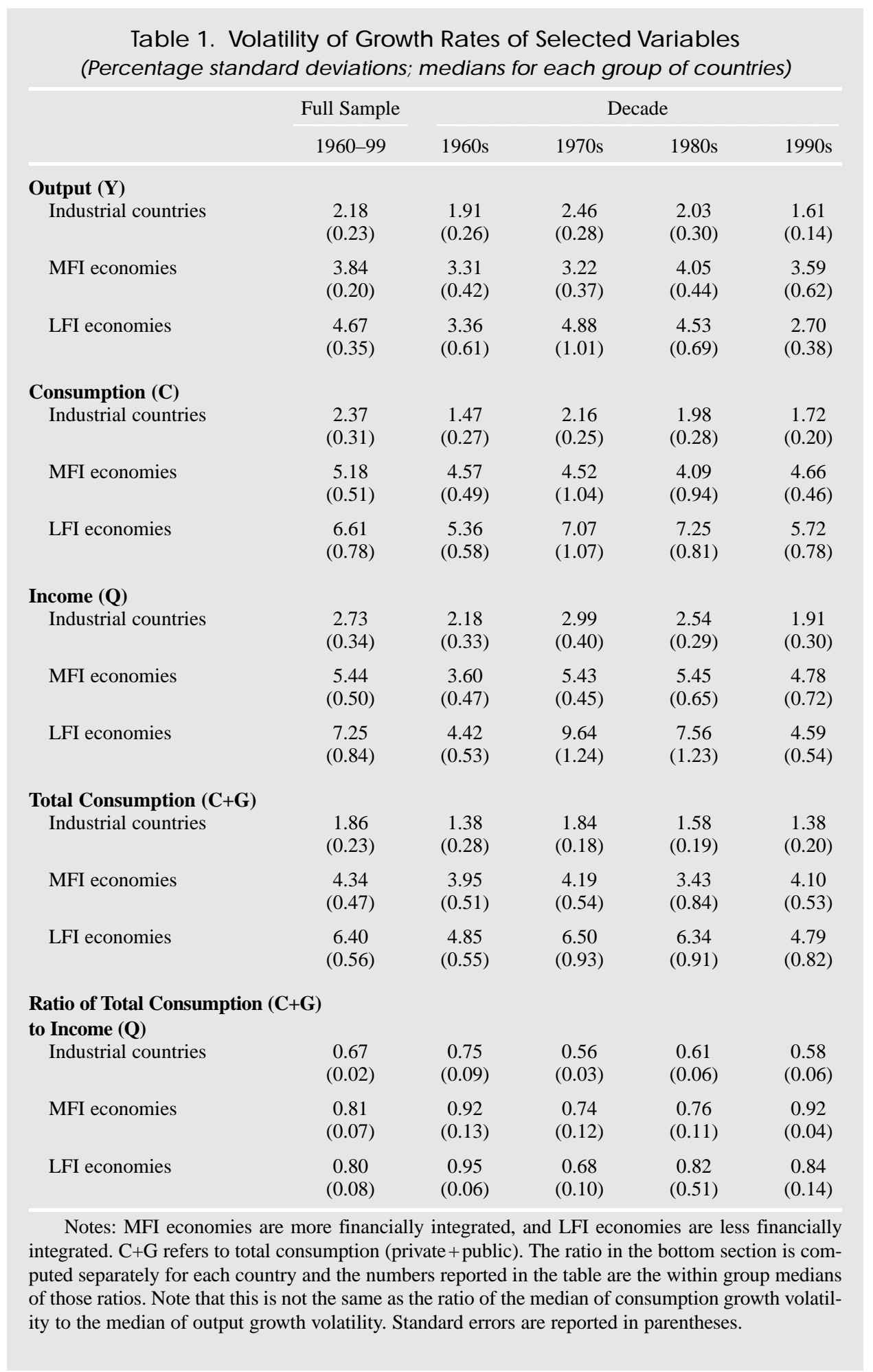


M. Ayhan Kose, Eswar S. Prasad, and Marco E. Temones

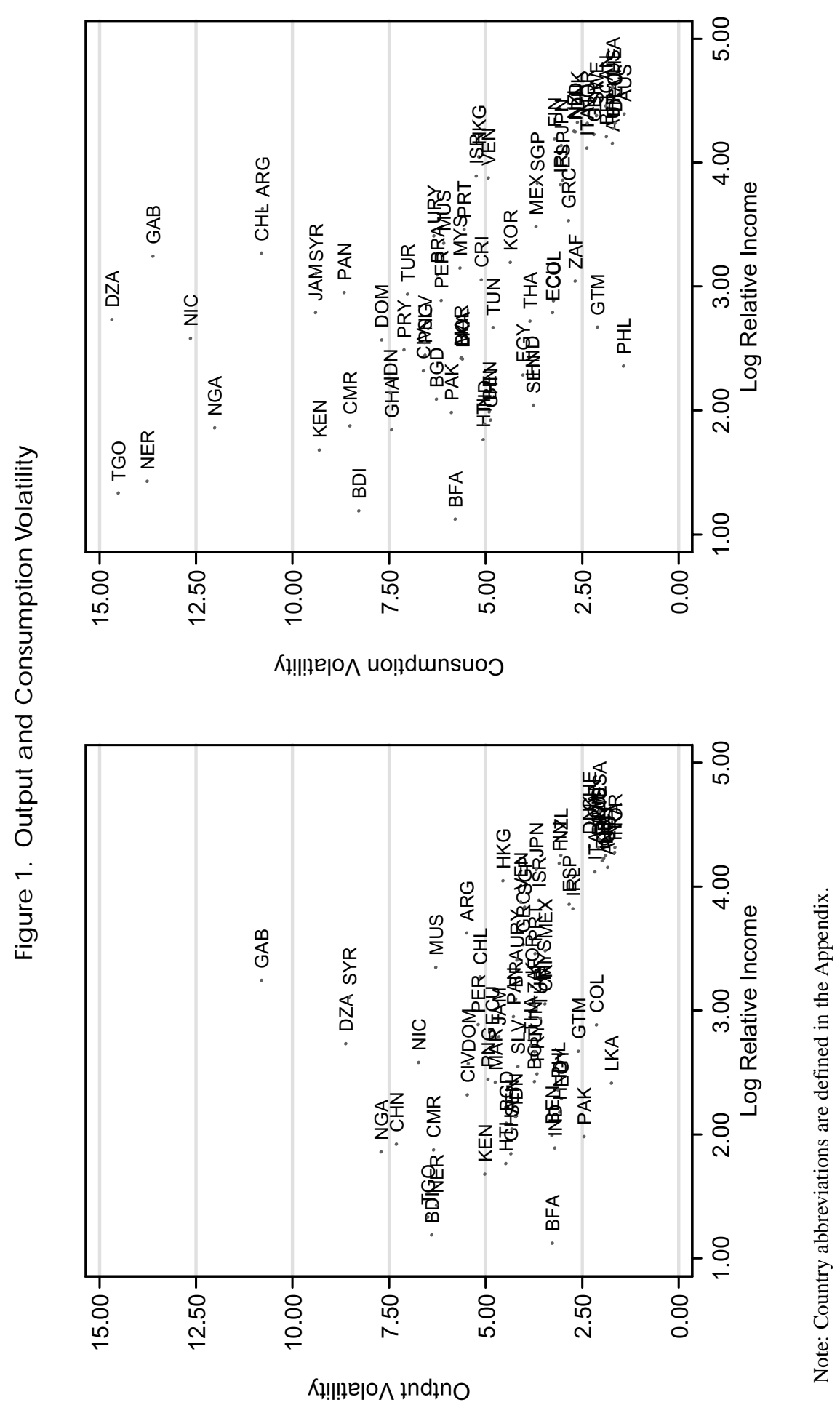


commonly regarded as an important determinant of macroeconomic volatility, especially in small developing economies. Furthermore, such shocks tend to be highly persistent and can have significant effects on permanent incomes of these economies. Following authors such as Kraay and Ventura (2002), we incorporate terms of trade effects by adding to each country's output its export price index times the share of exports to GDP minus its import price index times the share of imports to GDP.

This broader measure of income is substantially more volatile than output. Table 1 shows that the median standard deviation of income growth volatility for MFIEs is 5.44, compared to 3.84 for output growth. For LFIEs, the corresponding numbers are 7.25 and 4.67 , respectively.

The utility of a representative agent in a national economy depends not just on private consumption $(C)$ but also on government consumption $(G) .{ }^{10}$ The cyclical properties of $G$ could in fact influence the response of $C$ to macroeconomic shocks. Hence, it would be more appropriate to consider the sum of $C$ and $G$ rather than just $C$. This could be particularly important for less developed economies as well as more open economies that tend to have higher ratios of $G$ to $Y$.

Table 1 also shows that the median volatility of $C+G$ growth is indeed lower than that of $C$. For instance, for MFIEs, the median percentage standard deviation of the volatility of $C+G$ growth is 4.34 , compared to 5.18 for $C$ growth. For LFIEs, on the other hand, the comparable numbers-6.40 and 6.61, respectivelyare not that different. In other words, total consumption is on average less volatile than private consumption for industrial countries and MFIEs.

The bottom of Table 1 shows the median of the ratio of the volatility of total consumption to that of income. This can be considered a measure of the efficacy of consumption smoothing, at the national level, relative to income volatility. This ratio is significantly lower for industrial countries than for developing countries, but is essentially the same, on average, for MFIEs and LFIEs.

\section{Macroeconomic Volatility Over Time}

We now present an overview of changes in macroeconomic volatility over time. ${ }^{11}$ Table 1 (columns 2-5) presents summary statistics for the volatility of output over each of the last four decades. For industrial countries, median output volatility rose in the 1970s, the period of the major oil shock and the end of the Bretton Woods regime. By the 1990s, however, median output volatility had declined to a level lower than that of even the relatively calm 1960s. There is a similar pattern of a sharp decline in output volatility in the 1990s for LFIEs. Interestingly, output volatility for the MFIEs increased slightly in the 1980s and then remained essentially unchanged in the subsequent decade. A similar pattern holds for the volatility of income although, as noted earlier, income volatility tends to be much higher than output volatility, especially for developing economies.

\footnotetext{
${ }^{10}$ Conceptually, the flow of services from government expenditures would be the right measure to use. But data constraints force us to use total government expenditures as a proxy.

${ }^{11}$ Some recent studies also examine the time profile of the volatility of output and consumption of different groups of countries. For example, Osborn, van Dijk, and Sensier (2002) study the G-7 countries, and Kim, Kose, and Plummer (2003) examine the Asian emerging market countries.
} 


\section{Ayhan Kose, Eswar S. Prasad, and Marco E. Terrones}

Figure 2 shows mean output and income volatility for different groups of countries based on standard deviations of growth rates computed over a 10-year rolling window. Clearly, the choice of the cross-sectional average measure (mean vs. median) and the breakdown of the data in Table 1 into decade averages are not crucial to the results.

Table 1 shows the evolution of median volatility of the growth rates of private and total consumption. For industrial countries, there is a small decline in the volatility of consumption in the 1990s, relative to the two previous decades. For LFIEs, there is a particularly sharp and statistically significant decline in measures of consumption volatility in the 1990s relative to the 1980s and 1970s. The major difference is again for MFIEs, which actually experienced an increase in their median consumption volatility in the 1990s, although this increase is not statistically significant.

Figure 3, which plots mean volatility of private and total consumption for the three groups of countries, confirms these results and shows how consumption volatility for MFIEs and LFIEs has converged in the 1990s, with most of this convergence attributable to a decline in average volatility among LFIEs.

The obvious question at this stage is what these patterns imply for the relative volatility of consumption to income. As we have argued based on the analysis in the previous section, it is the volatility of total consumption relative to that of income that is the most relevant measure for analyzing the welfare effects, in terms of volatility, of financial integration. The bottom of Table 1 shows how this measure has evolved over the four decades.

A particularly interesting result is that the median relative volatility of total consumption to that of income has risen from the 1980s to the 1990s for MFIEs, precisely in the period when financial integration should have paid off in terms of better consumption-smoothing opportunities and, therefore, lower relative volatility of consumption for these economies. The increase in relative volatility is attributable to the decline in income volatility and the concomitant increase in consumption volatility.

Industrial countries and LFIEs, on the other hand, had virtually no change in their average relative volatilities from the 1980s to the 1990s. It should be noted that, even among industrial countries, gross capital flows surged after the mid1980s. Thus, the effects of capital market integration appear to have had very different effects on different groups of economies. In particular, the divergence in the evolution of consumption and income volatility of MFIEs runs exactly counter to the notion that financial integration increases risk-sharing and consumptionsmoothing opportunities.

In addition to averages, it is also of interest to see how this measure of relative volatility changed from the 1980s to the 1990s for individual developing economies. The top panel of Figure 4 shows that there are a number of MFIEs for which this ratio is significantly higher in the 1990s than in the 1980s. Countries like Argentina, Indonesia, and Turkey, on the other hand, appear to have fared better in terms of volatility in the 1990s than in the 1980s (our dataset ends in 1999-the subsequent developments in some of these countries would further support our observation). This figure clearly shows that our use of a measure of the volatility of consumption 

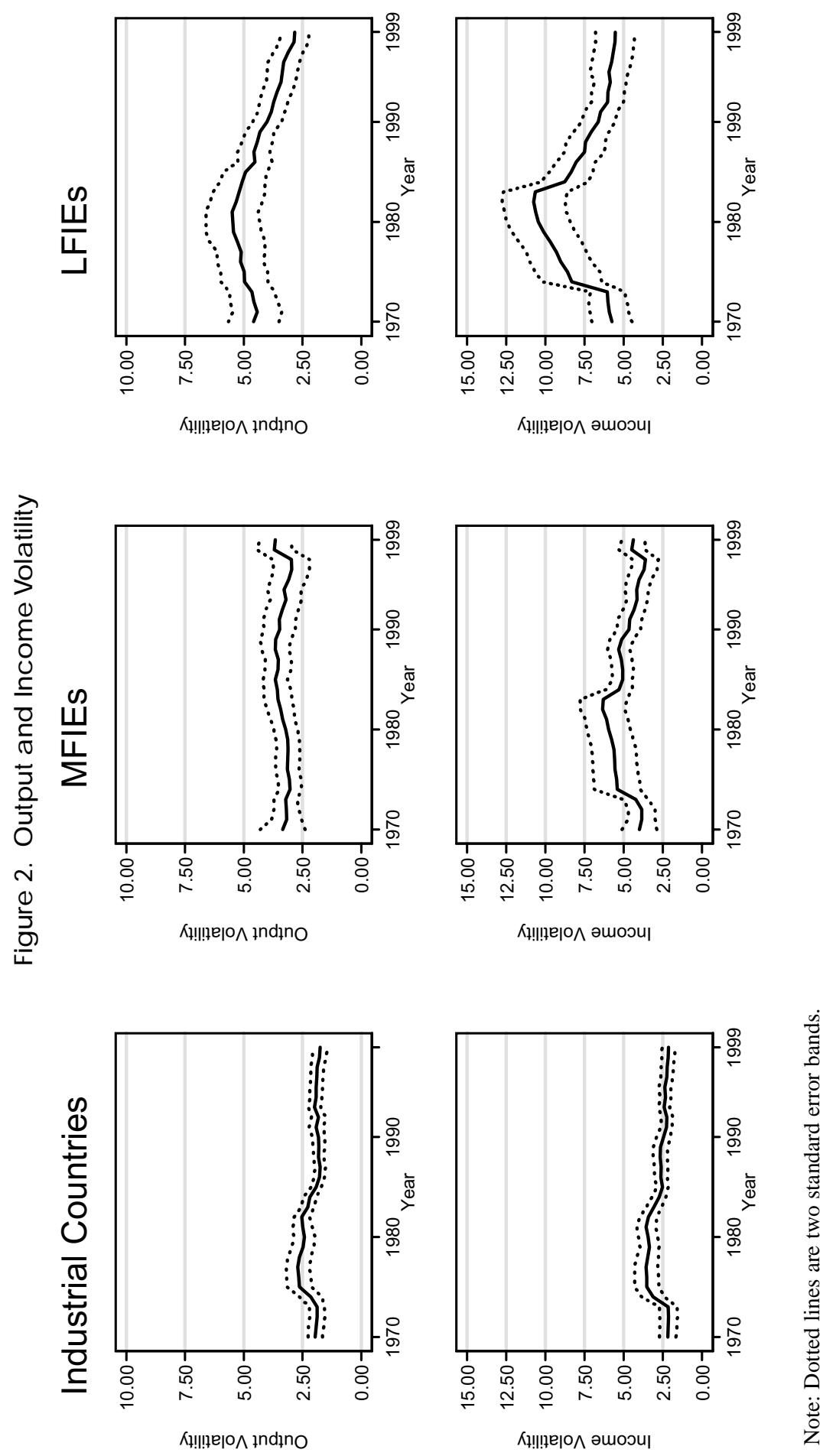

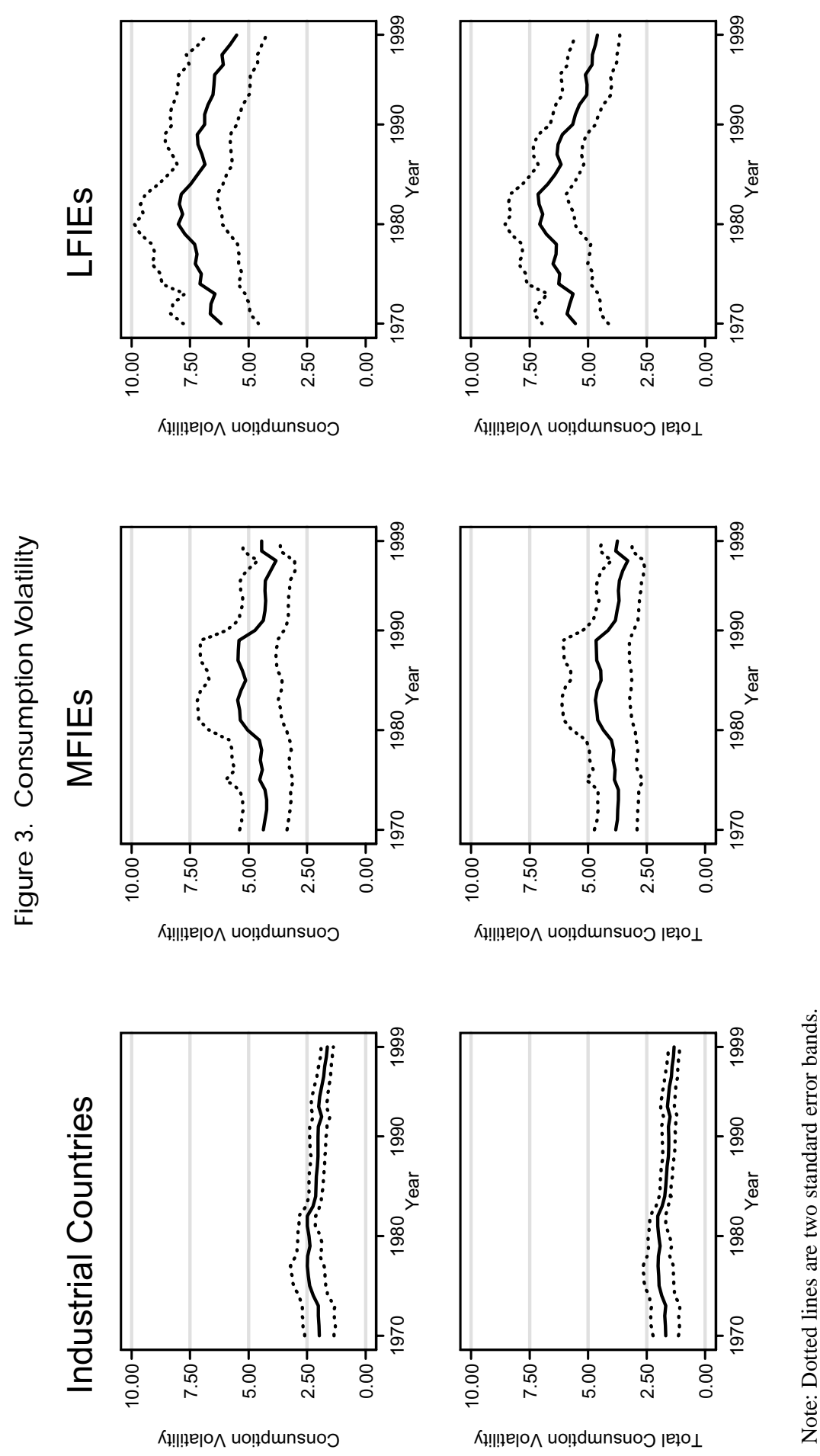
relative to that of income implies that this result can not be explained away as just a consequence of some of these economies having undergone crises during this period. Among LFIEs, the picture is mixed. A number of Latin American countries such as Panama, Uruguay, and Ecuador appear to have experienced higher relative volatility going from the 1980s to the 1990s, while many African countries had a decline in relative volatility.

The descriptive statistics in this section, while interesting in terms of providing a broad characterization of volatility dynamics over time, are of course only suggestive. In addition, we have used a coarse disaggregation of countries based on their degree of financial integration. Even among these groups of countries, there are substantial differences in terms of the degree of financial integration and how this has evolved over time. Hence, we now proceed to a regression analysis of volatility dynamics.

\section{Regression Analysis}

In this section, we provide a more formal regression analysis to understand the main determinants of macroeconomic volatility. In particular, we examine the roles of trade and financial openness in driving the cross-sectional and time series patterns of volatility. We use two measures of trade openness-a measure of restrictions on current account transactions and a standard trade openness ratio (ratio of imports and exports to GDP). To measure financial openness, we use an indicator of the restrictions on capital account transactions and also a measure of gross capital flows to GDP, where the latter is analogous to the trade openness ratio. The restrictiveness indicators can be considered as measures of de jure trade and financial openness while the flow measures capture de facto openness. ${ }^{12}$ This distinction is of particular importance in understanding the effects of financial integration as many economies that have maintained controls on capital account transactions have found them ineffective in many circumstances, particularly in the context of episodes of capital flight. We also consider potential nonlinear relations between macroeconomic volatility and the measures of trade and financial openness.

In the empirical analysis, we also include a number of variables drawn from papers that have examined various aspects of volatility. In addition to the measures of trade and financial openness, our core set of explanatory variables includes the level of per capita income, the standard deviation of the terms of trade, the ratio of M2 to GDP and the volatility of changes in this ratio, the levels and volatility of inflation, and the fiscal balance (impulse). We also explore the sensitivity of our results to the inclusion of a large number of other controls.

We eschew the use of fixed-effects estimators in order to avoid restricting the empirical analysis to within-country volatility. Most of the variation in our sample comes from the between-country component, which is of far more relevance for the issues that we are interested in. Instead of fixed effects, we include in the analysis

\footnotetext{
${ }^{12}$ The restrictiveness indicators are binary $0-1$ variables, where 1 indicates the presence of restrictions. For the regressions, they are averaged over each decade for each country and can, therefore, take values between 0 and 1. See Prasad, Wei, and Kose (2003) for a discussion of these alternative definitions of trade and financial openness and their implications for empirical analysis.
} 
M. Ayhan Kose, Eswar S. Prasad, and Marco E. Temones

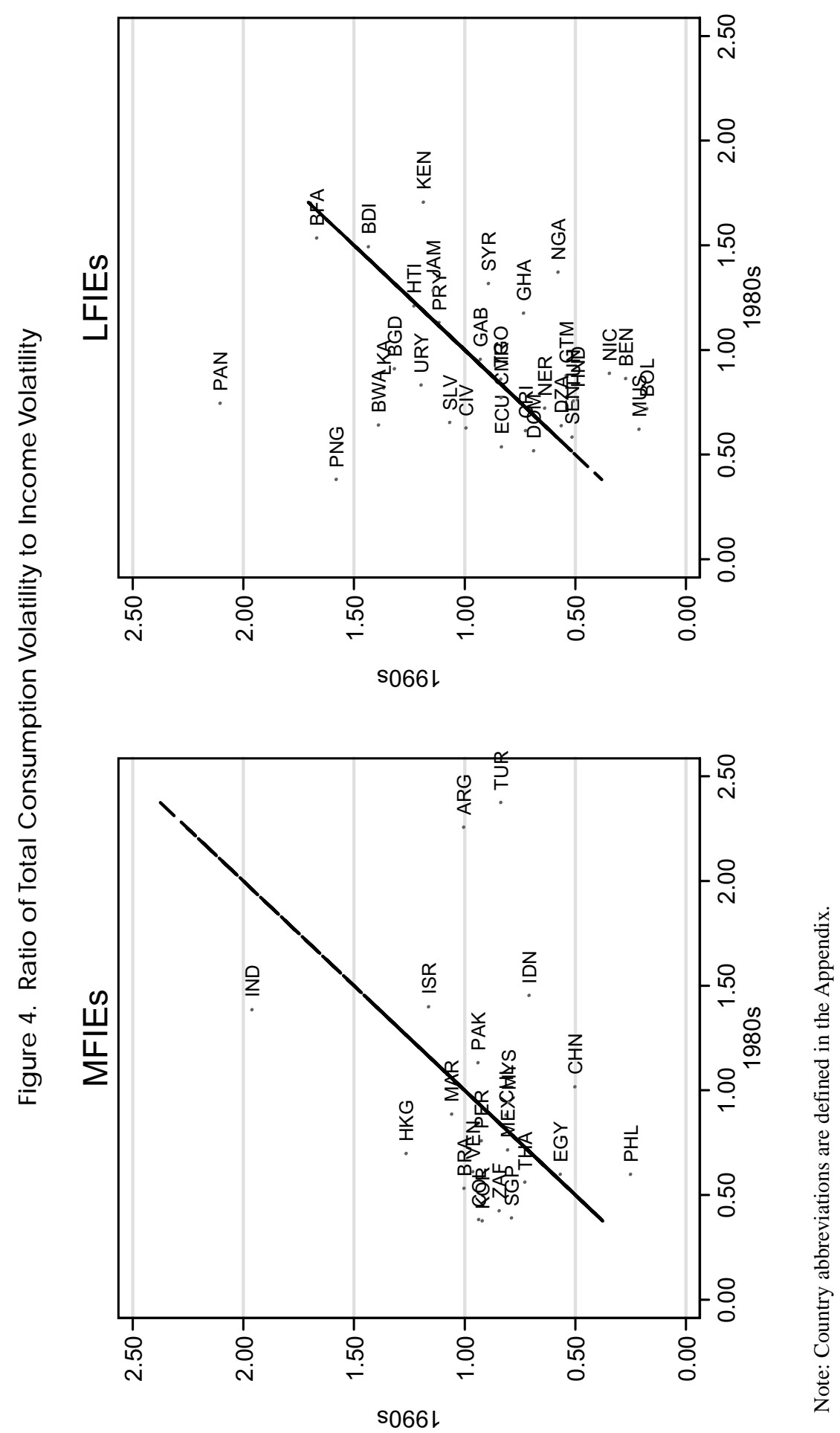


numerous country-specific variables-reflecting economic and political structures and other relevant features-that are potentially important for explaining crosscountry differences in volatility.

In our baseline regressions, we use data for each of the four decades in our sample. The dependent variable is the standard deviation of the growth rate of the relevant variable over each 10 -year period. Correspondingly, the explanatory variables are 10-year averages of the underlying annual data or, in the cases of other variables, volatility measures constructed in a manner similar to the dependent variables. All of the regressions reported below include time effects (decade dummies). We first report OLS results and then, in order to control for the potential endogeneity of the openness measures, also look at instrumental variables (IV) estimates.

The first two columns of Table 2 show the results for output and income, respectively. For both these variables, trade openness appears to be positively associated with volatility, suggesting that more open economies are more vulnerable to external shocks. As expected, the coefficient is larger for the income measure, which includes the effects of terms of trade fluctuations. Capital account openness, as measured by the restrictiveness indicator, is associated with higher output volatility, but this coefficient is only marginally significant. The volatility of the terms of trade is an important determinant of output as well as income volatility. The ratio of M2 to GDP is often interpreted as a measure of financial deepening. Consistent with the results of authors such as Denizer, Iyigun, and Owen (2002), we find that financial sector development, as proxied by this measure, is in fact associated with lower output volatility. Variability of the fiscal impulse measure contributes at best weakly to aggregate volatility.

As discussed earlier, theory does not provide a clear guide to the effects of financial and trade integration on output volatility. On the other hand, at least in the case of financial integration, the implication of standard stochastic dynamic business cycle models is that, for a given level of output volatility, financial integration should provide an avenue for increased international risk-sharing and, by extension, lower consumption volatility.

The third and fourth columns of Table 2 show that trade openness has a positive effect on the volatility of private consumption as well as that of total consumption. This is presumably related to the earlier result that trade openness increases output and income volatility. Financial integration, as proxied by the restrictiveness variable, seems to have only a marginal effect on the volatility of either measure of consumption. Gross capital flows, on the other hand, have a positive effect on total consumption volatility at low levels of capital flows. Notice that the coefficient on the quadratic term (square of the gross flows measure) enters with a significantly negative coefficient. The implication of this result is discussed in more detail below.

Relative income has a strongly negative effect on consumption volatility. In other words, high-income countries appear to have much lower levels of consumption volatility than low-income countries, even though they do not have much lower output volatility. Other variables like financial deepening and the volatility of the M2/GDP ratio seem to affect consumption volatility in much the same way that they affect output and income volatility. 


\section{Ayhan Kose, Eswar S. Prasad, and Marco E. Terrones}

\begin{tabular}{|c|c|c|c|c|c|}
\hline $\begin{array}{l}\text { Dependent variable } \\
\text { (volatility of growth rate of): }\end{array}$ & $\begin{array}{l}\text { Output } \\
\text { (Y) }\end{array}$ & $\begin{array}{l}\text { Income } \\
\text { (Q) }\end{array}$ & $\begin{array}{c}\text { Consumption } \\
\text { (C) }\end{array}$ & $\begin{array}{c}\text { Total } \\
\text { Consumption } \\
(\mathrm{C}+\mathrm{G})\end{array}$ & $\begin{array}{c}\text { Ratio of } \\
\mathrm{C}+\mathrm{G} \text { Volatility } \\
\text { to Q Volatility }\end{array}$ \\
\hline Current account restrictions & $\begin{array}{c}0.058 \\
(0.387)\end{array}$ & $\begin{array}{c}0.049 \\
(0.575)\end{array}$ & $\begin{array}{c}0.730 \\
(0.630)\end{array}$ & $\begin{array}{c}0.603 \\
(0.461)\end{array}$ & $\begin{array}{l}4.554 \\
(6.160)\end{array}$ \\
\hline Trade openness & $\begin{array}{l}0.014^{* *} \\
(0.006)\end{array}$ & $\begin{array}{l}0.059^{* *} \\
(0.014)\end{array}$ & $\begin{array}{l}0.031^{* * * *} \\
(0.012)\end{array}$ & $\begin{array}{l}0.018^{* *} \\
(0.007)\end{array}$ & $\begin{array}{l}-0.385^{* * *} \\
(0.095)\end{array}$ \\
\hline Capital account restrictions & $\begin{array}{r}0.578^{*} \\
(0.335)\end{array}$ & $\begin{array}{c}0.213 \\
(0.471)\end{array}$ & $\begin{array}{r}0.930^{*} \\
(0.557)\end{array}$ & $\begin{array}{c}0.611 \\
(0.450)\end{array}$ & $\begin{array}{l}8.447 \\
(6.092)\end{array}$ \\
\hline Financial openness & $\begin{array}{c}0.005 \\
(0.025)\end{array}$ & $\begin{array}{l}-0.030 \\
(0.043)\end{array}$ & $\begin{array}{c}0.071 \\
(0.052)\end{array}$ & $\begin{array}{c}0.054 \\
(0.034)\end{array}$ & $\begin{array}{l}1.107^{* * *} \\
(0.414)\end{array}$ \\
\hline $\begin{array}{l}\text { Financial openness squared } \\
\text { (divided by 100) }\end{array}$ & $\begin{array}{l}-0.015 \\
(0.027)\end{array}$ & $\begin{array}{l}-0.004 \\
(0.046)\end{array}$ & $\begin{array}{l}-0.100 \\
(0.056)\end{array}$ & $\begin{array}{l}-0.072^{* *} \\
(0.036)\end{array}$ & $\begin{array}{l}-1.125^{* * *} \\
(0.426)\end{array}$ \\
\hline Relative income & $\begin{array}{c}-1.050 \\
(0.641)\end{array}$ & $\begin{array}{c}-0.739 \\
(0.822)\end{array}$ & $\begin{array}{c}-1.476^{*} \\
(0.873)\end{array}$ & $\begin{array}{l}1.931^{* * *} \\
(0.678)\end{array}$ & $\begin{array}{c}-31.806^{* * *} \\
(11.399)\end{array}$ \\
\hline Terms of trade volatility & $\begin{array}{l}6.381^{* *} \\
(2.463)\end{array}$ & $\begin{array}{l}28.479^{* * *} \\
(4.736)\end{array}$ & $\begin{array}{l}20.229^{* * *} \\
(4.680)\end{array}$ & $\begin{array}{l}15.898^{* * *} \\
(3.354)\end{array}$ & $\begin{array}{r}-43.896 \\
(31.782)\end{array}$ \\
\hline M2/GDP & $\begin{array}{c}-0.014^{* *} \\
(0.007)\end{array}$ & $\begin{array}{c}-0.015 \\
(0.010)\end{array}$ & $\begin{array}{c}-0.035^{* * *} \\
(0.011)\end{array}$ & $\begin{array}{c}-0.026^{* * *} \\
(0.009)\end{array}$ & $\begin{array}{c}-0.286^{* *} \\
(0.129)\end{array}$ \\
\hline Volatility of M2/GDP & $\begin{array}{l}0.344^{* * *} \\
(0.114)\end{array}$ & $\begin{array}{c}0.374^{* *} \\
(0.158)\end{array}$ & $\begin{array}{l}0.544^{* * *} \\
(0.163)\end{array}$ & $\begin{array}{l}0.393^{* * *} \\
(0.131)\end{array}$ & $\begin{array}{c}3.703^{* *} \\
(1.767)\end{array}$ \\
\hline Average inflation & $\begin{array}{c}-0.238 \\
(0.156)\end{array}$ & $\begin{array}{c}0.161 \\
(0.240)\end{array}$ & $\begin{array}{c}-0.007 \\
(0.285)\end{array}$ & $\begin{array}{l}-0.270 \\
(0.205)\end{array}$ & $\begin{array}{c}-4.788^{* *} \\
(2.276)\end{array}$ \\
\hline Fiscal policy volatility & $\begin{array}{c}1.459^{*} \\
(0.775)\end{array}$ & $\begin{array}{c}-0.769 \\
(1.343)\end{array}$ & $\begin{array}{c}1.840 \\
(2.553)\end{array}$ & $\begin{array}{c}2.927 \\
(1.935)\end{array}$ & $\begin{array}{l}44.844^{* *} \\
(20.944)\end{array}$ \\
\hline $\mathrm{R}$ squared & 0.29 & 0.59 & 0.41 & 0.45 & 0.26 \\
\hline Number of observations & 264 & 264 & 264 & 264 & 264 \\
\hline $\begin{array}{l}\text { Notes: The dependent va } \\
\text { over each } 10 \text {-year period. C+ } \\
\text { dependent variable is the ratic } \\
\text { growth. The explanatory vari } \\
\text { of some variables, volatility } n \\
\text { growth rate of the relevant } \\
\text { regressions include time eff } \\
\text { errors are reported in parenth } \\
\text { percent, } 5 \text { percent, and } 1 \text { per }\end{array}$ & $\begin{array}{l}\text { able is the s } \\
\text { refers to t } \\
\text { of the stand } \\
\text { les are } 10- \\
\text { easures (ov } \\
\text { riable or th } \\
\text { cts (decade } \\
\text { ses. The sy } \\
\text { nt levels, re }\end{array}$ & $\begin{array}{l}\text { indard devi } \\
\text { al consump } \\
\text { d deviation } \\
\text { ear average } \\
\text { each deca } \\
\text { standard d } \\
\text { dummies). } \\
\text { bols * }{ }^{* *}, \text { a }\end{array}$ & $\begin{array}{l}\text { iation of the gr } \\
\text { ption (private }+ \\
\mathrm{n} \text { of total consu } \\
\text { es of the under } \\
\text { ide) constructec } \\
\text { deviation of ch } \\
\text { Heteroscedast } \\
\text { and }{ }^{* * *} \text { indicate }\end{array}$ & $\begin{array}{l}\text { rowth rate of the } \\
\text { + public). In the } \\
\text { umption growth } \\
\text { lying annual da } \\
\text { d as the standar } \\
\text { tanges in the re } \\
\text { ticity-consisten } \\
\text { e statistical sign }\end{array}$ & $\begin{array}{l}\text { relevant variable } \\
\text { final column, the } \\
\text { to that of income } \\
\text { a or, in the cases } \\
\text { I deviation of the } \\
\text { levant ratios. All } \\
\text { robust standard } \\
\text { ficance at the } 10\end{array}$ \\
\hline
\end{tabular}


A more important criterion to judge the relevance of trade and financial integration for developing economies, in particular, is related to their effects on the ratio of consumption growth volatility to that of income growth volatility. The last column contains a regression of the ratio of the volatility of total consumption growth to that of income growth on the same set of independent variables. One interesting result is that trade openness has a negative effect on this ratio. Although trade openness increases both consumption and income volatility, the net effect is to reduce the relative volatility of consumption.

More importantly, the coefficients on the financial openness variables are now strongly significant - the coefficient on the linear term is strongly positive while that on the quadratic is negative. ${ }^{13}$ In other words, increasing financial openness is associated with rising relative volatility of consumption, but only up to a certain threshold. The coefficient estimates indicate that this threshold is approximately 49 percent (ratio to GDP). Economies with gross flows that amount to a higher fraction of GDP seem to start seeing some of the benefits of capital market integration in terms of improved consumption-smoothing possibilities. Indeed, these levels of gross capital flows as a share of GDP are typically experienced over sustained periods of time only by some industrial countries. It is also the case that relative per capita income is strongly negatively correlated with this ratio. Thus, even after controlling for the level of economic development, the level of capital market integration has a nonlinear effect on volatility. ${ }^{14}$

Terms of trade volatility do not affect the relative volatility of consumption, although that is because this variable increases both consumption and income volatility. Domestic financial liberalization reduces not only consumption

and income volatility but also the ratio of the two. Although our measure of financial deepening is not an entirely adequate one, the strength of this relationship shows how the depth of domestic financial markets has a crucial impact on volatility. We also note that, while the variability of the fiscal impulse measure does not directly affect either consumption or income volatility, it does have a positive effect on the ratio.

We explored the robustness of our results in a number of different dimensions. In the interest of brevity, these results are only briefly described here. Firstly, instead of decade averages, we constructed data based on a five-year period. This increases the number of observations for each country. Not surprisingly, the point estimates do indeed differ but the main coefficients of interest remained statistically significant and of roughly similar magnitudes as in Table 2. Secondly, we also experimented with the inclusion of numerous other policy and macroeconomic variables-the level and variability of government expenditures to GDP, variability of inflation, the

${ }^{13}$ Higher order polynomials of the financial openness variable were not significant and did not greatly affect the coefficient estimates from the regressions reported above. Polynomials of the trade openness variable were also not significant.

${ }^{14}$ When we included the volatility of capital flows as a separate regressor, it did not appear to have significant explanatory power in the output and consumption regressions. However, in the regressions for the ratio of consumption volatility to income volatility, it enters with a small negative coefficient, although the coefficient is at best very marginally significant. This appears to be because it increases income volatility marginally while it has little effect on consumption volatility. None of the other coefficient estimates in Table 2 were materially affected by the inclusion of this variable. 


\section{Ayhan Kose, Eswar S. Prasad, and Marco E. Terrones}

composition of output, etc. None of these had a significant effect on aggregate volatility and are, therefore, excluded from the baseline regressions.

A potentially more important concern about the OLS results is that the different measures of openness may be endogenously determined. For instance, an increase in domestic volatility could induce policymakers to impose capital account restrictions and thereby attempt to control the component of volatility attributable to volatile capital flows. Furthermore, the degree of volatility in a given country could influence the level of capital flows and, possibly, even that of trade flows, to that country. Statistical tests for endogeneity such as the Hausman test do not reveal any strong evidence of such endogeneity (see the bottom row of Table 3). ${ }^{15}$ Nevertheless, this remains a concern at a conceptual level. Hence, we also explored an IV estimation strategy. This approach also has the advantage of controlling for possible measurement error in the openness variables, which is a particular concern for the capital flow data. We use a broad range of instruments for the four openness measures (see notes to Table 3). ${ }^{16}$

Table 3 contains IV estimates that can be compared with the OLS estimates in Table 2.17 There are some important differences relative to the OLS results. For instance, volatility of the fiscal impulse measure no longer seems to have a significant effect on the volatility of the macroeconomic aggregates shown in the table. In addition, the statistical significance of the trade openness measure is now limited to the regressions for income and the relative volatility of consumption (columns 2 and 5). Furthermore, financial deepening still has a negative effect on output and both private and total consumption volatility, but its effect on the relative volatility of consumption is no longer statistically significant.

Nevertheless, our core results about the effects of openness on relative volatility are preserved. In particular, two key results - the negative effects of trade openness on the ratio of consumption volatility to income volatility, and the nonlinear effect of financial openness on this ratio-are, if anything, strengthened by instrumenting them. The coefficients on the linear and quadratic terms indicate that the threshold at which financial openness begins to exert a negative effect on the relative volatility of consumption is about 50 percent (as a ratio to GDP), almost identical to the threshold derived from the OLS estimates. Overall, we view the IV results as broadly supportive of our main OLS results.

\section{Conclusions}

Assessing the benefits and costs associated with financial globalization requires a clear understanding of the impact of international financial integration on macroeconomic volatility. This paper has attempted to shed light on the effects

\footnotetext{
${ }^{15}$ The Hausman test is really more a test of the consistency of the OLS relative to IV estimates, but is often used as a test for endogeneity.

${ }^{16}$ The Sargan test, which was used to test the adequacy of the instruments, indicated that the null hypothesis that the instruments are uncorrelated with the error terms could not be rejected. Furthermore, the test confirmed that the instruments are validly excluded from the estimated regressions.

${ }^{17}$ Due to data limitations, our sample size shrinks by about 10 percent when we move to the IV estimation. We reestimated the OLS equations over this slightly smaller sample and did not find any major differences compared to the results reported in Table 2.
} 
FINANCIAL INTEGRATION AND MACROECONOMIC VOLATILTTY

\section{Table 3. Panel Regressions - Instrumental Variables Estimates}

\begin{tabular}{|c|c|c|c|c|c|}
\hline $\begin{array}{l}\text { Dependent variable } \\
\text { (volatility of growth rate of): }\end{array}$ & $\begin{array}{l}\text { Output } \\
\text { (Y) }\end{array}$ & $\begin{array}{l}\text { Income } \\
\text { (Q) }\end{array}$ & $\begin{array}{l}\text { Consumption } \\
\text { (C) }\end{array}$ & $\begin{array}{l}\text { Total } \\
\text { Consumption } \\
(\mathrm{C}+\mathrm{G})\end{array}$ & $\begin{array}{l}\text { Ratio of } \\
\text { C+G Volatility } \\
\text { to Q Volatility }\end{array}$ \\
\hline Current account restrictions & $\begin{array}{l}0.256 \\
(0.525)\end{array}$ & $\begin{array}{c}0.027 \\
(0.684)\end{array}$ & $\begin{array}{c}0.834 \\
(0.784)\end{array}$ & $\begin{array}{c}0.902 \\
(0.640)\end{array}$ & $\begin{array}{c}4.660 \\
(7.886)\end{array}$ \\
\hline Trade openness & $\begin{array}{c}0.039 \\
(0.026)\end{array}$ & $\begin{array}{l}0.130^{* * *} \\
(0.031)\end{array}$ & $\begin{array}{c}0.064 \\
(0.044)\end{array}$ & $\begin{array}{c}0.053 \\
(0.037)\end{array}$ & $\begin{array}{l}-0.722^{* *} \\
(0.361)\end{array}$ \\
\hline Capital account restrictions & $\begin{array}{c}0.184 \\
(0.451)\end{array}$ & $\begin{array}{l}-0.961 \\
(0.794)\end{array}$ & $\begin{array}{l}1.009 \\
(0.823)\end{array}$ & $\begin{array}{c}0.519 \\
(0.692)\end{array}$ & $\begin{array}{l}18.896^{* *} \\
(9.475)\end{array}$ \\
\hline Financial openness & $\begin{array}{l}-0.018 \\
(0.147)\end{array}$ & $\begin{array}{l}-0.340 \\
(0.226)\end{array}$ & $\begin{array}{c}0.302 \\
(0.211)\end{array}$ & $\begin{array}{c}0.252 \\
(0.180)\end{array}$ & $\begin{array}{l}5.716^{* *} \\
(2.750)\end{array}$ \\
\hline $\begin{array}{l}\text { Financial openness squared } \\
\text { (divided by 100) }\end{array}$ & $\begin{array}{l}-0.065 \\
(0.190)\end{array}$ & $\begin{array}{c}0.236 \\
(0.266)\end{array}$ & $\begin{array}{l}-0.422 \\
(0.301)\end{array}$ & $\begin{array}{l}-0.386 \\
(0.267)\end{array}$ & $\begin{array}{l}-5.768^{*} \\
(3.324)\end{array}$ \\
\hline Relative income & $\begin{array}{l}-0.339 \\
(0.920)\end{array}$ & $\begin{array}{c}1.183 \\
(1.348)\end{array}$ & $\begin{array}{l}-2.295^{* *} \\
(1.161)\end{array}$ & $\begin{array}{l}-2.217^{* *} \\
(0.947)\end{array}$ & $\begin{array}{l}-56.929^{* * *} \\
(16.267)\end{array}$ \\
\hline Terms of trade volatility & $\begin{array}{l}5.325^{* *} \\
(2.695)\end{array}$ & $\begin{array}{l}27.864^{* * *} \\
(5.254)\end{array}$ & $\begin{array}{l}19.608^{* * *} \\
(5.470)\end{array}$ & $\begin{array}{l}15.505^{* * *} \\
(4.222)\end{array}$ & $\begin{array}{l}-23.238 \\
(46.217)\end{array}$ \\
\hline M2/GDP & $\begin{array}{l}-0.020^{* *} \\
(0.008)\end{array}$ & $\begin{array}{l}-0.017 \\
(0.014)\end{array}$ & $\begin{array}{l}-0.036^{* *} \\
(0.014)\end{array}$ & $\begin{array}{l}-0.032^{* * *} \\
(0.012)\end{array}$ & $\begin{array}{l}-0.226 \\
(0.173)\end{array}$ \\
\hline Volatility of M2/GDP & $\begin{array}{l}0.481^{* *} \\
(0.157)\end{array}$ & $\begin{array}{l}0.460^{* * *} \\
(0.223)\end{array}$ & $\begin{array}{l}0.771^{* * *} \\
(0.284)\end{array}$ & $\begin{array}{l}0.590^{* *} \\
(0.243)\end{array}$ & $\begin{array}{c}4.091 \\
(2.633)\end{array}$ \\
\hline Average inflation & $\begin{array}{c}-0.306 \\
(0.227)\end{array}$ & $\begin{array}{c}-0.111 \\
(0.275)\end{array}$ & $\begin{array}{c}0.093 \\
(0.408)\end{array}$ & $\begin{array}{c}-0.181 \\
(0.296)\end{array}$ & $\begin{array}{c}-1.355 \\
(4.629)\end{array}$ \\
\hline Fiscal policy volatility & $\begin{array}{c}1.613 \\
(1.023)\end{array}$ & $\begin{array}{c}0.019 \\
(1.412)\end{array}$ & $\begin{array}{c}2.147 \\
(3.143)\end{array}$ & $\begin{array}{c}2.968 \\
(2.391)\end{array}$ & $\begin{array}{c}40.039 \\
(30.071)\end{array}$ \\
\hline Number of observations & 235 & 235 & 235 & 235 & 235 \\
\hline Hausman test statistic & $\begin{array}{l}11.130 \\
{[0.68]}\end{array}$ & $\begin{array}{c}24.310 \\
{[0.04]}\end{array}$ & $\begin{array}{l}10.140 \\
{[0.75]}\end{array}$ & $\begin{array}{r}6.340 \\
{[0.96]}\end{array}$ & $\begin{array}{l}15.130 \\
{[0.37]}\end{array}$ \\
\hline Sargan test & $\begin{array}{l}15.715 \\
{[0.11]}\end{array}$ & $\begin{array}{l}15.289 \\
{[0.12]}\end{array}$ & $\begin{array}{l}11.291 \\
{[0.34]}\end{array}$ & $\begin{array}{r}9.946 \\
{[0.45]}\end{array}$ & $\begin{array}{l}11.109 \\
{[0.35]}\end{array}$ \\
\hline
\end{tabular}

Notes: The dependent variable is the standard deviation of the growth rate of the relevant variable over each 10 -year period. $\mathrm{C}+\mathrm{G}$ refers to total consumption (private + public). In the final column, the dependent variable is the ratio of the standard deviation of total consumption growth to that of income growth. The explanatory variables are 10-year averages of the underlying annual data or, in the cases of some variables, volatility measures (over each decade) constructed as the standard deviation of the growth rate of the relevant variable or the standard deviation of changes in the relevant ratios. All regressions include time effects (decade dummies). The following variables were used as instruments: export proceed restrictions, multiple exchange regimes, Reinhart-Rogoff exchange rate arrangement, world real interest rate (deflated by each country's export price index), share of oil exports in total exports, initial levels of relative income and trade openness (in 1960), shares of manufactures and agricultural production in GDP, fraction of a country's territory subject to tropical climate, access to sea, fraction of the population that lives in rural areas, and Banks's weighted conflict index. Heteroscedasticity-consistent robust standard errors are reported in parentheses. The symbols *, **, and $* * *$ indicate statistical significance at the 10 percent, 5 percent, and 1 percent levels, respectively. The Hausman statistic tests whether there is a systematic difference between the coefficients of the IV regression and corresponding OLS regression. The Sargan test is for the validity of the instruments used in each regression. p-values are reported in brackets. 


\section{Ayhan Kose, Eswar S. Prasad, and Marco E. Terrones}

of financial integration on volatility. First, we have examined the implications of economic theory for the effects of financial integration on volatility. We have concluded that economic theory does not provide a clear guide to the effects of or financial integration on output volatility. In our empirical work, we have found that the volatility of output growth has, on average, declined in the 1990s relative to the three earlier decades. More importantly though, the volatility of consumption growth relative to that of income growth has on average increased for MFIEs in the 1990s, during which financial integration, as measured by financial flows to these economies, increased substantially. Our findings also indicate that financial openness, as measured by gross capital flows as a ratio to GDP, is associated with an increase in the ratio of consumption volatility to income volatility, contrary to the notions of improved international risk-sharing opportunities through financial integration. However, this relationship is nonlinear. Once the level of gross capital flows crosses a particular threshold, it appears to have a negative effect on this ratio.

These findings illustrate the complex relationship between international financial integration and macroeconomic stability. Could one easily argue that crises that took place in several emerging market economies during the 1990s show that international financial integration increases macroeconomic volatility? Our simple answer is "no," as the empirical evidence clearly shows that the volatility of output growth has, on average, declined in the 1990s relative to the three earlier decades. While financial openness seems to be associated with an increase in the ratio of consumption volatility to income volatility, once the level of gross capital flows crosses a particular threshold, it appears to have a negative effect on this ratio. In other words, developing countries need to be more, not less, integrated to the world financial markets to be able to reap the benefits of financial integration in terms of improved risk sharing. This conclusion requires further qualification as international financial integration is associated with a variety of risks. To minimize these risks, developing countries perhaps would need to implement sound macroeconomic and structural frameworks. For example, our findings emphasize the role of fiscal and monetary policies in driving macroeconomic volatility. In regards to structural reforms, our results suggest that the development of a domestic financial sector is critical as a high degree of financial sector development is associated with lower macroeconomic volatility.

We conclude the paper by laying out the agenda for extending the analysis in this paper. A first priority is to extend the scope of empirical work to provide a set of robust stylized facts that can help guide the theory. In this context, it is important to check systematically for threshold effects in the relationships between openness and volatility. Understanding the impact of openness on the dynamics of other major macroeconomic aggregates is also critical. The second, but equally important, priority is to develop a theoretical framework for understanding the linkages between openness and the dynamics of volatility that we have uncovered in this paper. 


\section{FINANC IAL INTEGRATION AND MACROECONOMIC VOLATILTTY}

\section{APPENDIX}

In this appendix, we describe the main variables used in the analysis and the main data sources. We also list the countries in the sample, along with the country groupings used in the analysis.

\section{Variable Description}

Real GDP, constant local currency units.

Real income (adjusted for terms of trade), constant local currency units.

GDP at PPP rates, current international dollars.

Private consumption, constant local currency units.

General government consumption, constant local currency units.

Imports of goods and services, current and constant in U.S. dollars.

Exports of goods and services, current and constant in U.S. dollars.

Trade openness. Sum of exports and imports divided by GDP.

Capital inflows, percent of GDP. Sum of foreign direct investment, portfolio flows, and other investments.

Capital outflows, percent of GDP. Sum of foreign direct investment, portfolio flows, and other investments.

Financial openness. Gross capital flows (sum of capital inflows and outflows).

Terms of trade $(1995=100)$.

IMF

Trade and capital account restrictions. Includes payment restrictions for current and capital account, export surrender requirements, and multiple exchange rates.

Consumer price index $(1995=100)$.

WDI, IFS

Money and quasi-money (M2), percent of GDP.

WDI

Government expenditures, total, local currency units.

IMF

IFS
Source

World Development Indicators (WDI)

Easterly and Sewadeh (2001)

WDI

WDI

WDI, International Financial Statistics (IFS)

WDI, IFS
IFS,

Lane and Milesi-Ferretti (2001, 2003)

IFS,

Lane and Milesi-Ferretti (2001, 2003) 


\section{Ayhan Kose, Eswar S. Prasad, and Marco E. Terrones}

Government revenues, total, local currency units.

Ratio of government expenditures to revenues.

LIBOR interest rate, London, six months.

Exchange rate arrangement, de facto.

Population.

Share of the population that lives in rural areas.

Shares of manufactures and agricultural production in GDP.

Weighted conflict index.
IFS

IFS

Reinhart and Rogoff

WDI

WDI

WDI

Banks's Cross-National Time Series Data Archive

The sample comprises 76 countries-21 industrial and 55 developing. ${ }^{18}$

\section{Industrial Countries}

Australia (AUS), Austria (AUT), Belgium (BEL), Canada (CAN), Denmark (DNK), Finland (FIN), France (FRA), Germany (DEU), Greece (GRC), Ireland (IRL), Italy (ITA), Japan (JPN), Netherlands (NLD), New Zealand (NZL), Norway (NOR), Portugal (PRT), Spain (ESP), Sweden (SWE), Switzerland (CHE), United Kingdom (GBR), and United States (USA).

\section{Developing Countries}

These countries are grouped into MFIEs (22) and LFIEs (33). ${ }^{19}$

MFIES

Argentina (ARG), Brazil (BRA), Chile (CHL), China (CHN), Colombia (COL), Egypt (EGY), Hong Kong (HKG), India (IND), Indonesia (IDN), Israel (ISR), Korea (KOR), Malaysia (MYS), Mexico (MEX), Morocco (MAR), Pakistan (PAK), Peru (PER), Philippines (PHL), Singapore (SGP), South Africa (ZAF), Thailand (THA), Turkey (TUR), and Venezuela (VEN).

\section{LFIEs}

Algeria (DZA), Bangladesh (BGD), Benin (GEN), Bolivia (BOL), Botswana (BWA), Burkina Faso (BFA), Burundi (BDI), Cameron (CMR), Costa Rica (CRI), Cote d'Ivoire (CIV), Dominican Republic (DOM), Ecuador (ECU), El Salvador (SLV), Gabon (GAB), Ghana (GHA), Guatemala (GTM), Haiti (HTI), Honduras (HND), Jamaica (JAM), Kenya (KEN), Mauritius (MUS), Nicaragua (NIC), Niger (NER), Nigeria (NGA), Panama (PAN), Papua New Guinea (PNG), Paraguay (PRY), Senegal (SEN), Sri Lanka (LKA), Syrian Arab Republic (SYR), Togo (TGO), Tunisia (TUN), and Uruguay (URY).

\footnotetext{
${ }^{18}$ We excluded from the analysis small countries (those with population below one million), transition economies, some oil producers, and other countries with incomplete or clearly unreliable data.

${ }^{19}$ Hong Kong and Panama were excluded from the regression analysis because of problems with data on capital flows.
} 


\section{FINANC IAL INTEGRATION AND MACROECONOMIC VOLATILTTY}

\section{REFERENCES}

Aghion, P., A. Banerjee, and T. Piketty, 1999, "Dualism and Macroeconomic Volatility," Quarterly Journal of Economics, Vol. 114, pp. 1359-97.

Arellano, C., and E.G. Mendoza, 2002, "Credit Frictions and Sudden Stops in Small Open Economies: An Equilibrium Business Cycle Framework for Emerging Markets Crises," NBER Working Paper No. 8880 (Cambridge, Massachusetts: National Bureau of Economic Research).

Baxter, M., and M. Crucini, 1995, "Business Cycles and the Asset Structure of Foreign Trade," International Economic Review, Vol. 36, pp. 821-54.

Bekaert, G., C.R. Harvey, and C. Lundblad, 2002, "Growth Volatility and Equity Market Liberalization,” Working Paper (Durham, North Carolina: Duke University).

Blankenau, W., M.A. Kose, and K. Yi, 2001, “Can World Real Interest Rates Explain Business Cycles in a Small Open Economy?" Journal of Economic Dynamics and Control, Vol. 25, pp. 867-89.

Buch, C.M., J. Dopke, and C. Pierdzioch, 2002, "Financial Openness and Business Cycle Volatility," Working Paper (Kiel: Kiel Institute for World Economics).

Caballero, R.J., and A. Krishnamurthy, 2001, "International and Domestic Collateral Constraints in a Model of Emerging Market Crises," Journal of Monetary Economics, Vol. 48, pp. 513-48.

Calvo, G., 1998, "Varieties of Capital-Market Crises," IEA Conference Volume, No. 118 (New York: St. Martin's Press; London: Macmillan Press).

Crucini, M., 1997, "Country Size and Economic Fluctuations," Review of International Economics, Vol. 5, No. 2, pp. 204-20.

Denizer, C.A., M.F. Iyigun, and A. Owen, 2002, "Finance and Macroeconomic Volatility," Contributions to Macroeconomics, Vol. 2, pp. 1-30.

Easterly, W., R. Islam, and J. E. Stiglitz, 2001, "Shaken and Stirred: Explaining Growth Volatility," Annual World Bank Conference on Development Economics, ed. by B. Pleskovic and N. Stern.

Easterly, W., and M. Sewadeh, 2001, Global development network growth database, http://www.worldbank.org/research/growth/GDNdata.htm

Edison, H. J., M. Klein, L. Ricci, and T. Slok, 2002, "Capital Account Liberalization and Economic Performance: Survey and Synthesis," IMF Working Paper No. 02/120 (Washington: International Monetary Fund).

Gavin, M., and R. Hausmann, 1996, "Sources of Macroeconomic Volatility in Developing Economies", IADB Working Paper (Washington: Inter-American Development Bank).

Glick, R., and M. Hutchison, 1999, "Banking and Currency Crises: How Common are Twin Crises?" in Financial Crises in Emerging Markets, ed. by R. Glick, R. Moreno, and M. Spiegel, (Cambridge: Cambridge University Press).

Head, A.C., 1995, "Country Size, Aggregate Fluctuations, and International Risk Sharing," Canadian Journal of Economics, Vol. 28, pp. 1096-19.

International Monetary Fund, 2002, World Economic Outlook, September (Washington).

Karras, G., and F. Song, 1996, "Sources of Business-Cycle Volatility: An Exploratory Study on a Sample of OECD Countries," Journal of Macroeconomics, Vol. 18, No. 4, pp. 621-37.

Kim, S.H., M.A. Kose, and M. Plummer, 2003, “Dynamics of Business Cycles in Asia," Review of Development Economics, forthcoming.

Kose, M.A., 2002, "Explaining business cycles in small open economies", Journal of International Economics, Vol. 56, pp. 299-327.

— Increasingly Globalized Economy?" Finance \& Development, Vol. 39, pp. 38-41.

Kose, M.A., and K. Yi, 2003, "The Trade-Comovement Problem in International Macroeconomics," IMF Working Paper, forthcoming (Washington: International Monetary Fund). 


\section{Ayhan Kose, Eswar S. Prasad, and Marco E. Terrones}

Kraay, A., and J. Ventura, 2002, "Comparative Advantage and Cross-Section of Business Cycles," MIT Working Paper (Cambridge, Massachusetts: Massachusetts Institute of Technology).

Krugman, P., 1993, "Lessons of Massachusetts for EMU," in The Transition to Economic and Monetary Union in Europe, ed. by F. Giavazzi and F. Torres (Cambridge: Cambridge University Press), pp. 241-61.

Lane, Philip, 2001, "The New Open Economy Macroeconomics: a Survey", Journal of International Economics, Vol. 54, pp. 235-66.

— , and G.M. Milesi-Ferretti, 2001, "The External Wealth of Nations: Estimates of Foreign Assets and Liabilities for Industrial and Developing Countries," Journal of International Economics, Vol. 55, pp. 263-94.

_ 2003, "International Financial Integration," IMF Staff Papers, Vol. 50 (Third Annual Research Conference Issue), pp. 82-114.

McConnell, M., and G. Perez-Quiros, 2000, "Output Fluctuations in the United States: What has Changed Since the Early 1980s?” American Economic Review, Vol. 90, pp. 1464-76.

Mendoza, E.G., 1994, “The Robustness of Macroeconomic Indicators of Capital Mobility," in Capital Mobility: The Impact on Consumption, Investment, and Growth, ed. by Leonardo Leiderman and Assaf Razin (Cambridge: Cambridge University Press), pp. 83-111.

_ 2002, "Credit, prices, and crashes: business cycles with a sudden stop,", in Preventing Currency Crises in Emerging Markets, ed. by Frankel, J., and S. Edwards, (Chicago: University of Chicago Press) forthcoming.

Obstfeld, M., and K. Rogoff, 1995, "Exchange Rate Dynamics Redux," Journal of Political Economy, Vol. 103, pp. 624-60.

O’Donnell, B., 2001, "Financial Openness and Economic Performance" (unpublished; Dublin: Trinity College).

Pallage, S., and M.A. Robe, 2003, "On the Welfare Cost of Economic Fluctuations in Developing Countries," International Economic Review, forthcoming.

Prasad, E., K. Rogoff, S. Wei, and M.A. Kose, 2003, “The Effects of Financial Globalization on Developing Countries: Some Empirical Evidence,” IMF Working Paper, forthcoming (Washington: International Monetary Fund).

Ramey, G., and V.A. Ramey, 1995, "Cross-Country Evidence on the Link Between Volatility and Growth," American Economic Review, Vol. 85, pp. 1138-51.

Razin, Assaf and Andrew K. Rose, 1994, "Business-Cycle Volatility and Openness: an Exploratory Cross-Sectional Analysis," in Capital Mobility: The Impact on Consumption, Investment, and Growth, ed. by Leonardo Leiderman and Assaf Razin (Cambridge: Cambridge University Press), pp. 48-76.

Reinhart, Carmen, and Kenneth Rogoff, 2002, “The Modern History of Exchange Rate Arrangements: A Reinterpretation," NBER Working Paper (Cambridge, Massachusetts: National Bureau of Economic Research).

Sarno, L., 2001, “Toward a New Paradigm in Open Economy Modeling: Where Do We Stand?" Review of Federal Reserve Bank of St Louis, Vol. 83, pp. 21-36.

Senay, O., 1998, "The Effects of Goods and Financial Market Integration on Macroeconomic Volatility," The Manchester School Supplement, Vol. 66, pp. 39-61.

Senhadji, A., 1998, "Dynamics of the Trade Balance and the Terms-of-Trade in LDCs: The S-Curve," Journal of International Economics, Vol. 46, pp. 105-31.

Sutherland, A., 1996, "Financial Market Integration and Macroeconomic Volatility," Scandinavian Journal of Economics, Vol. 98, pp. 521-39.

van Dijk, D., D.R. Osborn, and M. Sensier, 2002, "Changes in the Variability of the Business Cycle in the G7 Countries," Working Paper, (Manchester, England: University of Manchester). 